\title{
Effects of caffeine supplementation on physical performance and mood dimensions in elite and trained-recreational athletes
}

P. Jodra ${ }^{1,2+}$, A. Lago-Rodríguez ${ }^{3 * \dagger}$, A. J. Sánchez-Oliver ${ }^{4}$, A. López-Samanes ${ }^{5}$, A. Pérez-López ${ }^{6}$, P. Veiga-Herreros ${ }^{1}$, A. F. San Juan ${ }^{7+} \mathbb{D}$ and R. Domínguez ${ }^{3+}$

\begin{abstract}
Background: Caffeine supplementation (CAFF) has an established ergogenic effect on physical performance and the psychological response to exercise. However, few studies have compared the response to CAFF intake among athletes of different competition level. This study compares the acute effects of CAFF on anaerobic performance, mood and perceived effort in elite and moderately-trained recreational athletes.

Methods: Participants for this randomized, controlled, crossover study were 8 elite athletes (in the senior boxing national team) and 10 trained-recreational athletes. Under two experimental conditions, CAFF supplementation $(6 \mathrm{mg} / \mathrm{kg})$ or placebo $(\mathrm{PLAC})$, the athletes completed a Wingate test. Subjective exertion during the test was recorded as the rating of perceived exertion (RPE) both at the general level (RPE general $_{\text {) }}$ and at the levels muscular (RPE $E_{\text {muscular }}$ ) and cardiorespiratory (RPE $\left.E_{\text {cardio }}\right)$. Before the Wingate test, participants completed the questionnaires Profiles of Moods States (POMS) and Subjective Vitality Scale (SVS).

Results: In response to CAFF intake, improvements were noted in $W_{\text {peak }}(11.22 \pm 0.65$ vs $10.70 \pm 0.84 ; p=$ $\left.0.003 ; \eta_{p}^{2}=0.44\right), W_{\text {avg }}\left(8.75 \pm 0.55\right.$ vs $\left.8.410 .46 ; p=0.001 ; \eta_{p}^{2}=0.53\right)$ and time taken to reach $W_{\text {peak }}(7.56 \pm 1.58$ vs $9.11 \pm 1.53 ; p<0.001 ; \eta_{p}^{2}=0.57$ ) both in the elite and trained-recreational athletes. However, only the elite athletes showed significant increases in tension (+325\%), vigor (+31\%) and SVS (+ 28\%) scores after the intake of CAFF compared to levels recorded under the condition PLAC $(p<0.05)$. Similarly, levels of vigor after consuming CAFF were significantly higher in the elite than the trained-recreational athletes $(+5.8 \%)$.
\end{abstract}

Conclusions: CAFF supplementation improved anaerobic performance in both the elite and recreational athletes. However, the ergogenic effect of CAFF on several mood dimensions and subjective vitality was greater in the elite athletes.

Keywords: Caffeine, Sport supplementation, Athletes, Boxing, Ergogenic aid

\footnotetext{
* Correspondence: angel.lago@ui1.es

${ }^{\dagger}$ P. Jodra, A. Lago-Rodríguez, A. F. San Juan and R. Domínguez contributed equally to this work.

${ }^{3}$ Faculty of Health Sciences, Universidad Isabel I, Burgos, Spain

Full list of author information is available at the end of the article
}

(c) The Author(s). 2019 Open Access This article is distributed under the terms of the Creative Commons Attribution 4.0 International License (http://creativecommons.org/licenses/by/4.0/), which permits unrestricted use, distribution, and reproduction in any medium, provided you give appropriate credit to the original author(s) and the source, provide a link to the Creative Commons license, and indicate if changes were made. The Creative Commons Public Domain Dedication waiver (http://creativecommons.org/publicdomain/zero/1.0/) applies to the data made available in this article, unless otherwise stated. 


\section{Background}

Caffeine (CAFF) is a nutritional supplement with a high level of scientific evidence supporting its effect of improving sports performance [1]. This explains why CAFF has become one of the most widely consumed nutritional aids among athletes $[2,3]$, both professional $[4,5]$ and recreational/amateur $[6,7]$. Moreover, its popularity has also increased since it was removed from the list of banned substances for sports in 2004 [8].

As CAFF is molecularly similar to adenosine, it blocks adenosine receptors $A_{1}, A_{2 a}$ and $A_{2 b}$ [9], acting as a powerful central nervous system stimulator [10], and upregulating the synthesis of catecholamines with neurotransmitter activity (e.g., dopamine, epinephrine and norepinephrine) [11, 12]. As skeletal muscle has many adenosine receptors [13], CAFF intake increases neuromuscular recruitment $[14,15]$. Further, at the muscle tissue level, CAFF increases the frequency of calcium channel opening [16], promoting the release of calcium into the myoplasm and thus enhancing muscle contraction [17]. These effects make CAFF an effective ergogenic aid in various exercise actions such as endurance sports [18], exercise efforts with high glycolytic demands [19], resistance exercise [20], and racket [21], combat [22] and team sports [23].

Besides increasing catecholamine levels, the effects of CAFF supplementation on the central nervous system include increased sympathetic activity and reduced parasympathetic activity. In turn, these effects modify a person's mood [24, 25], enhancing alertness and reducing the feeling of fatigue [26, 27], such that there is a subjective perception of vitality when faced with a physical activity task. Increased perceived tension reflects optimization of the state of preparation of an athlete to undertake a physical test. The relationship between subjective tension and an athlete's preparation state follows a hump-shaped function, whereby levels of tension that are too low or too high will mean a decline in performance when adjusting to a person's optimal performance zone [28]. This explains the known effects of CAFF on emotional factors of tension and vigor, increasing their perceived levels and improving an individual's willingness to tackle the task at hand $[29,30]$. In turn, this reduces perceived effort levels (RPE), both in trained and untrained individuals [31].

With the objective of testing whether CAFF consumption is conditioned by an athlete's training level, Skinner et al. compared blood caffeine concentrations after taking an oral CAFF supplement in untrained subjects versus trained resistance sport athletes [32]. Results indicated that caffeine concentrations were higher in the trained athletes. This suggests that the ergogenic effect of CAFF supplementation could be associated with the training level (trained vs. untrained), and performance level (elite vs. recreational) of the athlete. Evidence supporting this theory is, however, scarce and results have been conflicting [13, 33-37]. Hence, while various studies have examined populations of athletes with different performance levels, so far no study has tried to assess whether an athlete's training level could determine the ergogenic effects of CAFF supplementation. The present study was therefore designed to compare the acute effects of CAFF supplementation on physical performance and mood when executing anaerobic efforts and to assess the effort perceived by elite athletes and moderately-trained recreational athletes.

\section{Methods \\ Participants}

Eighteen men were enrolled. Eight of these participants were elite athletes (age: $22.0 \pm 1.8$ years; body mass: $65.6 \pm 10.8 \mathrm{~kg}$; height: $1.69 \pm 0.09 \mathrm{~m}$; BMI: $22.7 \pm$ $1.3 \mathrm{~kg} / \mathrm{m}^{2}$ ), members of the Spanish national senior male boxing team who had been training at the High Performance Center in Madrid, Spain, and participating in international competitions for over 2 years. The remaining 10 subjects were undergraduate students from the Department of Sport Sciences of the Universidad de Alfonso X El Sabio, Madrid, Spain (age: $22.5 \pm 1.8$ years; body mass: $75.0 \pm 10.8 \mathrm{~kg}$; height: $1.75 \pm 0.04 \mathrm{~m}$; BMI: $\left.24.3 \pm 2.6 \mathrm{~kg} / \mathrm{m}^{2}\right)$. These subjects were categorized as recreational athletes based on the following criteria: (a) at least 3 years of experience with strength training, having completed within the past 18 months $\geq 3$ sessions/week without interruption; (b) a bench press one-repetition maximum (1 RM) greater than body weight, and a full squat 1 RM 1.5 times body weight [38]; (c) no nutritional supplements taken in the 3 months before the study outset; (d) no smoking; (e) no disease or other impediment that could affect cycle ergometry performance.

Participants in both experimental groups were volunteers who signed up for this study after an informative session held 1 week before the study outset. Candidates were first informed of the possible secondary effects of CAFF supplementation. The study protocol fulfilled the tenets of the Declaration of Helsinki, and was approved by the Ethics Committee of the Universidad Alfonso X El Sabio.

\section{Experimental design}

The study design was crossover, randomized, doubleblind, placebo-controlled. Each participant undertook two test sessions within $48 \mathrm{~h}$ at the university Exercise Physiology laboratory at the same time of day $( \pm 0.25 \mathrm{~h})$. In each session, $50 \%$ of the athletes were randomly assigned a CAFF $(6 \mathrm{mg} / \mathrm{kg})$ or placebo (PLAC) $(6 \mathrm{mg} / \mathrm{kg}$ of sucrose) supplement. 
Upon arrival at the laboratory for each session, participants were given a supplement (CAFF or PLAC) and after a $60 \mathrm{~min}$ period of rest, they completed the questionnaires profile of mood states (POMS) and subjective vitality scale (SVS). After a standardized warm-up, the subjects performed a Wingate test on a cycle ergometer to assess anaerobic performance [39]. Immediately after the test, they graded their exertion using the rate of perceived exertion (RPE) scale.

\section{Nutritional intervention}

Caffeine supplements were provided in \#1 nontransparent red capsules (Guinama S.L.U, 0044634, La Pobla de Valbona, Spain). Individual capsules were prepared based on each participant's body weight, so each capsule supplied $6 \mathrm{mg} / \mathrm{kg}$ of either CAFF or PLAC to each participant. Capsules were prepared following the standard work procedure described in the Formulario Nacional Español using a semi-automatic manual filling machine Capsunorm 2000 (Miranda de Ebro, Spain). The timing of supplement intake was based on the fact that peak blood caffeine levels are reached $1 \mathrm{~h}$ postingestion [40] and on the results of a disaggregation quality assay described in the Real Farmacopea Española (2005) of 13.4 $\mathrm{min}$ [41].

In line with previous research [42], subjects were provided with a set of guidelines to ensure each individual ingested similar proportions of carbohydrates $(60 \%)$, lipids (30\%) and proteins (10\%), aiming at avoiding interactions between the supplementation and any nutritional factor. The intake of caffeine was also restricted $24 \mathrm{~h}$ before the study start and the subjects were provided with a list of foodstuffs rich in caffeine (coffee, tea, mate, energizing drinks, cola drinks, chocolate drinks and chocolate) they should avoid.

\section{Profile of mood states (POMS)}

To assess the participants' mood, we used the profile of mood states (POMS) questionnaire in its original reduced version [43], translated into Spanish and validated by Fuentes et al. [44]. Participants graded a set of 29 items related to mood on a Likert scale from 0 (not at all) to 4 (extremely) in reply to the question "How do you feel at this moment?" to assess six scales: tension, depression, anger, vigor, fatigue and confusion.

\section{Subjective vitality scale (SVS)}

Participants' vitality was assessed using the Spanish version of the subjective vitality scale (SVS) [45] of Balaguer et al. [46]. Subjects are required to indicate their agreement with seven statements related to subjective feelings of energy and vitality using a 7-point Likert scale where 1 means "total disagreement" and 7 means "total agreement".

\section{Anaerobic performance}

A Monark cycle ergometer (Ergomedic 828E, Vansbro, Sweden) was used for the Wingate test. The test was preceded by a standardized warm up as described previously [42, 47] and consisted of $30 \mathrm{~s}$ of cycling at maximum effort with a load (Kp) corresponding to $7.5 \%$ of the subject's body weight. The test was started from a stop position and the first round of pedaling initiated with the dominant leg. Participants were encouraged to reach the maximum rpm in the shortest time possible and try to maintain this pedaling speed until the end of the test. Throughout the test, the athletes were motivated by 5 investigators.

Power (W) was recorded during each second of the test. The following variables were subsequently calculated: the highest $\mathrm{W}$ value recorded during the test or peak power (Wpeak), the time in seconds (s) taken to reach Wpeak (Time Wpeak), mean W for the test duration (Wmean) and minimum power (Wmin), taken as the lowest $\mathrm{W}$ recorded during the last $10 \mathrm{~s}$ of the test.

\section{Rating of perceived exertion (RPE)}

In line with previous research [48], a 6 to 20 RPE scale of Borg [49] was presented as soon as the Wingate test was finished. Accordingly, participants were first asked to report RPE regarding muscular pain felt at legs (RPEmuscular); second, participants were asked to report RPE only at cardiorespiratory level $\left(\mathrm{RPE}_{\text {cardio }}\right)$; and finally, participants had to declare global RPE ( $\left.\mathrm{RPE}_{\text {general }}\right)$, which included features from both muscular and cardiorespiratory dimensions.

\section{Statistical analysis}

Data are presented as means \pm standard deviations (SD). The normal distribution of data was tested using the Kolmogorov-Smirnov test, and equality of variances was established with the Levene's test. When an inequality of variances was found, a non-parametric test was used, in which case the value of the adjusted test statistic and degrees of freedom are reported. To ensure similar anthropometric and personal variables between elite and trained-recreational athletes, separate Student t-tests for independent samples (elite vs. trained-recreational) were run for age, weight, height, and body mass index (BMI), respectively.

To compare the effects of CAFF supplementation on physical and psychological measures between the two groups of athletes, separate $2 \times 2$ independent analyses of variance for repeated measures (ANOVA-RM) were applied for each variable recorded. Performance level (elite vs. trained-recreational) was introduced as an inter-subject factor, whereas Supplementation (CAFF vs. PLAC) was used as an intra-subject factor. Practical significance for pairwise comparisons was assessed by 
calculating Cohen's $d$ effect size [50]. Effect sizes (d) of above 0.8 , between 0.8 and 0.5 , between 0.5 and 0.2 and lower than 0.2 were considered as large, moderate, small, and trivial, respectively [51]. Further, ANOVA-RM effect sizes were calculated using partial eta squared $\left(\eta_{p}^{2}\right)$, and $<$

$0.25,0.26-0.63$ and $>0.63$ considered small, medium and large effect sizes respectively [52, 53]. All statistical tests were performed using the Statistical Package for Social Sciences (version 20.0 for Mac, SPSS ${ }^{\mathrm{in}}$ Inc., Chicago, IL, USA). Significance was set at $p<0.05$.

\section{Results}

No significant differences between experimental groups (elite vs. trained- recreational) were detected in the variables age $\left(\mathrm{t}_{16}=0.593 ; p=0.561 ; d=0.28\right)$; weight $\left(\mathrm{t}_{16}=\right.$ $1.838 ; p=0.085 ; d=0.87)$; height $\left(t_{9.41}=1.694 ; p=0.123\right.$; $d=0.87)$; and BMI ( $\left.\mathrm{t}_{16}=1.594 ; p=0.130 ; d=0.76\right)$.

\section{Anaerobic performance}

The results found for the anaerobic performance measures are summarized in Table 1. A significant effect of the factors supplementation $\left(\mathrm{F}_{1,16}=12.804 ; p=0.003 ; \eta_{p}^{2}\right.$ $=0.44)$ and group $\left(\mathrm{F}_{1,16}=8.915 ; p=0.009 ; \eta_{p}^{2}=0.36\right)$ was observed when peak power was analyzed. Thus, participants showed higher $\mathrm{W}_{\text {peak }}$ values after CAFF supplementation compared to placebo (11.22 \pm 0.65 vs $10.7 \pm$ $0.84 \mathrm{~W})$ whereas trained-recreational athletes showed a higher $W_{\text {peak }}(11.31 \pm 0.73)$ than the elite athletes $(10.52 \pm 0.62)$. However, there was no significant interaction between supplementation and group $\left(\mathrm{F}_{1,16}=\right.$ 0.652; $p=0.431 ; \eta_{p}^{2}=0.04$ ).

For the average power exerted by participants during the Wingate test, we observed a significant effect of supplementation $\left(\mathrm{F}_{1,16}=18.099 ; p=0.001 ; \eta_{p}^{2}=0.531\right)$. Participants showed a greater $W_{\text {avg }}$ after CAFF supplementation $(8.75 \pm 0.55)$ compared to placebo $(8.41 \pm 0.46)$. No significant supplementation by group interaction emerged $\left(\mathrm{F}_{1,16}=1.197 ; p=0.290 ; \eta_{p}^{2}=\right.$ 0.07 ); nor did we observe a significant effect of group $\left(\mathrm{F}_{1,16}=0.820 ; p=0.378 ; \eta_{p}^{2}=0.05\right)$.

As for minimum power in the Wingate test, no significant supplementation by group interaction was detected $\left(\mathrm{F}_{1,16}=0.680 ; p=0.422 ; \eta_{p}^{2}=0.04\right)$. Neither were any significant effects observed of the factors supplementation $\left(\mathrm{F}_{1,16}=0.595 ; p=0.452 ; \eta_{p}^{2}=0.04\right)$ or group $\left(\mathrm{F}_{1,16}=\right.$ $0.948 ; p=0.345 ; \eta_{p}^{2}=0.06$ ).

Finally, when we examined the time it took the participants to achieve maximum power, a significant effect emerged of supplementation $\left(\mathrm{F}_{1,16}=21.138 ; p<0.001\right.$; $\left.\eta_{p}^{2}=0.57\right)$. This meant that the athletes reached $\mathrm{W}_{\text {peak }}$ earlier after CAFF supplementation $(7.56 \pm 1.58)$ compared to placebo $(9.11 \pm 1.53)$. There was no significant supplementation by group interaction $\left(\mathrm{F}_{1,16}=3.584 ; p=\right.$ $\left.0.077 ; \eta_{p}^{2}=0.18\right)$ or a significant effect of group $\left(\mathrm{F}_{1,16}=\right.$ $\left.0.079 ; p=0.783 ; \eta_{p}^{2}=0.005\right)$.

\section{Rating of perceived exertion (RPE)}

Table 2 details the ratings of perceived exertion awarded by the participants. A significant effect was detected for the factor group $\left(\mathrm{F}_{1,16}=6.507 ; p=0.021 ; \eta_{p}^{2}=0.29\right)$ in the exertion perceived by the athletes in the legs $\left(\mathrm{RPE}_{\text {muscular }}\right)$ whereby the trained-recreational athletes showed higher $\mathrm{RPE}_{\text {muscular }}(18.20 \pm 1.06)$ than the elite athletes $(15.75 \pm$ 3.17). There were no significant supplementation by group interactions $\left(\mathrm{F}_{1,16}=0.02 ; p=0.889 ; \eta_{p}^{2}=0.001\right)$, or significant effects of supplementation $\left(\mathrm{F}_{1,16}=0.376 ; p=\right.$ $0.548 ; \eta_{p}^{2}=0.02$ ).

A significant effect of the factor group was found in exertion perceived at the cardiorespiratory level $\left(\mathrm{F}_{1,16}=6.829\right.$;

Table 1 Performance variables recorded in each experimental group

\begin{tabular}{|c|c|c|c|c|c|c|}
\hline & & \multirow[t]{2}{*}{ Elite } & \multirow[t]{2}{*}{ Recreational } & \multicolumn{3}{|l|}{$p$-values (ES) } \\
\hline & & & & Supplementation & Group & Supplementation x Group \\
\hline \multirow[t]{2}{*}{$\mathrm{W}_{\max }$} & Caffeine & $10.85 \pm 0.48$ & $11.52 \pm 0.62$ & $0.003^{* *}(0.44)$ & $0.009^{* *}(0.36)$ & $0.431(0.04)$ \\
\hline & Placebo & $10.19 \pm 0.59$ & $11.11 \pm 0.8$ & & & \\
\hline \multirow[t]{2}{*}{$W_{\text {avg }}$} & Caffeine & $8.69 \pm 0.38$ & $8.8 \pm 0.67$ & $0.001^{* *}(0.53)$ & $0.378(0.07)$ & $0.290(0.05)$ \\
\hline & Placebo & $8.25 \pm 0.37$ & $8.54 \pm 0.51$ & & & \\
\hline \multirow[t]{2}{*}{$W_{\min }$} & Caffeine & $6.49 \pm 0.22$ & $6.01 \pm 1.1$ & $0.452(0.04)$ & $0.345(0.06)$ & $0.422(0.04)$ \\
\hline & Placebo & $6.19 \pm 0.56$ & $6.02 \pm 0.89$ & & & \\
\hline \multirow[t]{2}{*}{$T W_{\max }$} & Caffeine & $8.00 \pm 1.6$ & $7.2 \pm 1.55$ & $<0.001^{* * *}(0.57)$ & $0.783(0.05)$ & $0.077(0.18)$ \\
\hline & Placebo & $8.88 \pm 1.64$ & $9.3 \pm 1.49$ & & & \\
\hline
\end{tabular}

Data are provided as the mean \pm standard deviation. Adjusted values for the test statistic $(F)$ and degrees of freedom (df) are shown when inequality of variances were found between groups

Abbreviations: $E S$ : effect size; $W_{\text {max }}$ : maximum power; $W_{\text {avg }}$ : average power; $W_{\min }$ : minimum power; $T W_{\text {max }}$ : time to maximum power

${ }^{* *}: p<0.01{ }^{* * *}: p<0.001$ 
Table 2 Ratings of perceived exertion recorded in each experimental group

\begin{tabular}{|c|c|c|c|c|c|c|}
\hline & & \multirow[t]{2}{*}{ Elite } & \multirow[t]{2}{*}{ Recreational } & \multicolumn{3}{|l|}{ p-values (ES) } \\
\hline & & & & Supplementation & Group & Supplementation x Group \\
\hline \multirow[t]{2}{*}{ RPE $E_{\text {legs }}$} & Caffeine & $15.63 \pm 2.82$ & $18.00 \pm 1.15$ & $0.548(0.02)$ & $0.021^{*}(0.29)$ & $0.889(0.001)$ \\
\hline & Placebo & $15.88 \pm 3.68$ & $18.40 \pm 0.97$ & & & \\
\hline \multirow[t]{2}{*}{$\mathrm{RPE}_{\text {cardio }}$} & Caffeine & $14.50 \pm 3.62$ & $17.20 \pm 1.75$ & $0.419(0.04)$ & $0.019^{*}(0.30)$ & $0.785(0.05)$ \\
\hline & Placebo & $14.75 \pm 2.76$ & $17.70 \pm 1.57$ & & & \\
\hline \multirow[t]{2}{*}{$\mathrm{RPE}_{\text {general }}$} & Caffeine & $15.50 \pm 3.66$ & $17.70 \pm 1.16$ & $0.094(0.16)$ & $0.079(0.18)$ & $0.846(0.002)$ \\
\hline & Placebo & $16.13 \pm 3.48$ & $18.20 \pm 0.92$ & & & \\
\hline
\end{tabular}

Data are provided as the mean \pm standard deviation. Adjusted values for the test statistic $(\mathrm{F})$ and degrees of freedom (df) are shown when inequality of variances were found between groups

Abbreviations: $\mathrm{ES}$ : effect size; $\mathrm{RPE}_{\text {legs }}$ : exertion perceived at the level of the legs; $\mathrm{RPE}_{\text {cardio: }}$ exertion perceived at the cardiorespiratory level; $\mathrm{RPE} \mathrm{E}_{\mathrm{general}}$ : general perceived exertion

*: $p<0.05$

$\left.p=0.019 ; \eta_{p}^{2}=0.3\right)$ in that the trained-recreational athletes showed a larger $\operatorname{RPE}_{\text {cardio }}(17.45 \pm 1.64)$ than the elite athletes $(14.63 \pm 3.12)$. There was no significant supplementation by group interaction $\left(\mathrm{F}_{1,16}=0.077 ; p=0.785 ; \eta_{p}^{2}=\right.$ $0.005)$ nor significant effect of the factor supplementation $\left(\mathrm{F}_{1,16}=0.69 ; p=0.419 ; \eta_{p}^{2}=0.04\right)$.

No significant supplementation by group interaction $\left(\mathrm{F}_{1,16}=0.039 ; p=0.846 ; \eta_{p}^{2}=0.002\right)$ was found for the general rate of perceived exertion ( $\left.\mathrm{RPE}_{\text {general }}\right)$. Moreover, there was no significant effect of supplementation $\left(\mathrm{F}_{1,16}=3.172 ; p=0.094 ; \eta_{p}^{2}=0.16\right)$ or group $\left(\mathrm{F}_{1,16}=\right.$ 3.524; $p=0.079 ; \eta_{p}^{2}=0.18$ ).

\section{Psychological measures}

In Table 3, we provide the results found for the psychological measures. A significant supplementation by group interaction was noted for tension $\left(\mathrm{F}_{1,16}=6.526\right.$; $p=0.021 ; \eta_{p}^{2}=0.29$; Fig. 1a), which was accompanied by a significant effect of the factor supplementation $\left(\mathrm{F}_{1,16}=\right.$ $\left.16.552 ; p=0.001 ; \eta_{p}^{2}=0.51\right)$. However, no significant effect of group was observed $\left(\mathrm{F}_{1,16}=0.815 ; p=0.380 ; \eta_{p}^{2}=\right.$ $0.05)$. Our post-hoc pairwise analysis revealed significantly greater tension levels reported by the elite athletes after caffeine intake compared with placebo $(8 \pm 4.98$ vs. $1.88 \pm 3.56 ; p<0.001 ; d=1.43$ ).

A significant effect of the factor group was noted when depression measures were analyzed $\left(\mathrm{F}_{1,16}=5.24 ; p=\right.$ $\left.0.036 ; \eta_{p}^{2}=0.25\right)$. Elite athletes awarded more points to the dimension depression $(3.25 \pm 0.93)$ than the trainedrecreational athletes $(1.30 \pm 2.7)$. No significant supplementation by group interaction was observed $\left(\mathrm{F}_{1,16}=\right.$ $\left.1.474 ; p=0.242 ; \eta_{p}^{2}=0.08\right)$ nor a significant effect of supplementation $\left(\mathrm{F}_{1,16}=0.018 ; p=0.894 ; \eta_{p}^{2}=0.001\right)$.

For the dimension anger, there was no significant interaction between supplementation and group $\left(\mathrm{F}_{1,16}=\right.$ $1.481 ; p=0.241 ; \eta_{p}^{2}=0.08$ ) or any significant effects of supplementation $\left(\mathrm{F}_{1,16}=0.165 ; p=0.690 ; \eta_{p}^{2}=0.01\right)$ or group $\left(\mathrm{F}_{1,16}=1.967 ; p=0.180 ; \eta_{p}^{2}=0.11\right)$.

When measures of vigor were analyzed, a significant supplementation by group interaction was noted $\left(\mathrm{F}_{1,16}=\right.$ $11.284 ; p=0.004 ; \eta_{p}^{2}=0.41$; Fig. 1b), accompanied by a significant effect of supplementation $\left(\mathrm{F}_{1,16}=29.070 ; p<0.001\right.$; $\left.\eta_{p}^{2}=0.64\right)$. However, no significant effect was detected of the factor group $\left(\mathrm{F}_{1,16}=2.706 ; p=0.119 ; \eta_{p}^{2}=0.14\right)$. Our post-hoc pairwise analysis revealed significantly greater vigor values for the elite than trained- recreational athletes after caffeine supplementation ( $16,5 \pm 2.62$ vs. $13 \pm 3.02$; $p=0.20 ; d=1.24)$. Moreover, significantly higher vigor scores were obtained for the elite athletes when these were supplemented with caffeine rather than placebo $(16.5 \pm 2.62$ vs. $12.63 \pm 2.33 ; p<0.001 ; d=1.56)$. A significant effect of supplementation was also found on self-reported fatigue $\left(\mathrm{F}_{1,16}=9.164 ; p=0.008 ; \eta_{p}^{2}=0.36\right)$. Accordingly, participants showed higher fatigue levels after supplementation with placebo $(4.89 \pm 4.42)$ than CAFF $(2.56 \pm 2.77)$. There was no significant supplementation by group interaction $\left(\mathrm{F}_{1,16}=3.299 ; p=0.088 ; \eta_{p}^{2}=0.17\right)$ nor significant effect of group $\left(\mathrm{F}_{1,16}=0.850 ; p=0.370 ; \eta_{p}^{2}=0.05\right)$.

For confusion levels reported by the participants, there was no significant supplementation by group interaction $\left(\mathrm{F}_{1,16}=1.516 ; p=0.236 ; \eta_{p}^{2}=0.09\right)$, nor a significant effect of supplementation $\left(\mathrm{F}_{1,16}=0.257 ; p=0.619 ; \eta_{p}^{2}=\right.$ $0.02)$ or group $\left(\mathrm{F}_{1,16}=1.035 ; p=0.324 ; \eta_{p}^{2}=0.06\right)$.

As for the subjective vitality scale, a significant supplementation by group interaction was detected $\left(\mathrm{F}_{1,16}=\right.$ $11.028 ; p=0.004 ; \eta_{p}^{2}=0.41$; Fig. $1 \mathrm{c}$ ), along with a significant effect of supplementation $\left(\mathrm{F}_{1,16}=22.863 ; p<0.001\right.$; $\left.\eta_{p}^{2}=0.59\right)$ but no significant effect of group $\left(\mathrm{F}_{1,16}=\right.$ $0.292 ; p=0.597 ; \eta_{p}^{2}=0.02$ ). Post-hoc pairwise comparisons revealed that elite athletes returned higher SVS scores after caffeine supplementation compared to placebo ( $40.63 \pm 4.78$ vs. $31.75 \pm 7.78 ; p<0.001 ; d=1.41)$. 
Table 3 Psychological measures recorded in each experimental group

\begin{tabular}{|c|c|c|c|c|c|c|}
\hline & & Elite & Recreational & p-values (ES) & & \\
\hline & & & & Supplementation & Group & Supplementation x Group \\
\hline Tension & Caffeine & $8.00 \pm 4.99^{\dagger}$ & $4.30 \pm 3.77$ & $0.001^{* *}(0.51)$ & $0.380(0.05)$ & $0.021^{*}(0.29)$ \\
\hline & Placebo & $1.88 \pm 3.56$ & $2.90 \pm 2.18$ & & & \\
\hline Depression & Caffeine & $3.63 \pm 0.74$ & $1.00 \pm 1.25$ & $0.894(0.001)$ & $0.036^{*}(0.25)$ & $0.242(0.008)$ \\
\hline & Placebo & $2.88 \pm 0.99$ & $1.60 \pm 3.69$ & & & \\
\hline Anger & Caffeine & $0.38 \pm 1.06$ & $2.40 \pm 3.10$ & $0.690(0.01)$ & $0.180(0.08)$ & $0.241(0.11)$ \\
\hline & Placebo & $0.88 \pm 1.81$ & $1.40 \pm 2.46$ & & & \\
\hline Vigor & Caffeine & $16.50 \pm 2.62^{\dagger \#}$ & $13.00 \pm 3.02$ & $<0.001^{* * *}(0.64)$ & $0.119(0.14)$ & $0.004^{* *}(0.41)$ \\
\hline & Placebo & $12.62 \pm 2.33$ & $12.10 \pm 2.85$ & & & \\
\hline Fatigue & Caffeine & $2.50 \pm 3.50$ & $2.60 \pm 2.22$ & $0.008^{* *}(0.36)$ & $0.370(0.05)$ & $0.088(0.17)$ \\
\hline & Placebo & $6.50 \pm 4.54$ & $3.60 \pm 4.09$ & & & \\
\hline Confusion & Caffeine & $14.63 \pm 3.54$ & $12.20 \pm 3.99$ & $0.619(0.02)$ & $0.324(0.06)$ & $0.236(0.09)$ \\
\hline & Placebo & $14.13 \pm 4.36$ & $13.40 \pm 2.22$ & & & \\
\hline SVS & Caffeine & $40.63 \pm 4.78^{\dagger}$ & $38.40 \pm 5.44$ & $<0.001^{* * *}(0.59)$ & $0.597(0.02)$ & $0.004^{* *}(0.41)$ \\
\hline & Placebo & $31.75 \pm 7.78$ & $36.80 \pm 5.71$ & & & \\
\hline
\end{tabular}

Data are provided as the mean \pm standard deviation. Adjusted values for the test statistic $(F)$ and degrees of freedom (df) are shown when inequality of variances were found between groups

Abbreviations: SVS: subjective vitality scale; ES: effect size

${ }^{*}: p<0.05 ;{ }^{* *}: p<0.01 ;{ }^{* * *}: p<0.001 ;+$ : significant differences for caffeine versus placebo at the group level; \#: significant differences detected between elite and recreational athletes at the supplementation level

\section{Discussion}

The present study was designed to compare the acute effects of CAFF supplementation on anaerobic performance, mood and perceived exertion in elite athletes and moderately-trained recreational athletes. Our findings indicate that the ergogenic effect of CAFF is determined by an athlete's performance level but only in terms of variables related to mood state. Hence, elite athletes reported significantly higher tension levels following the intake of CAFF (+ 325\%) than the intake of PLAC. Similarly, CAFF supplementation led to significantly higher measures of vigor compared to the effect of PLAC (+ $31 \%)$ but only in the elite athletes. Further, vigor levels reported after the intake of CAFF were significantly higher $(+27 \%)$ in the elite athletes than recreational athletes. Finally, elite athletes also returned significantly higher SVS scores after the intake of CAFF compared to PLAC (+5.8\%). In contrast, it emerged that the

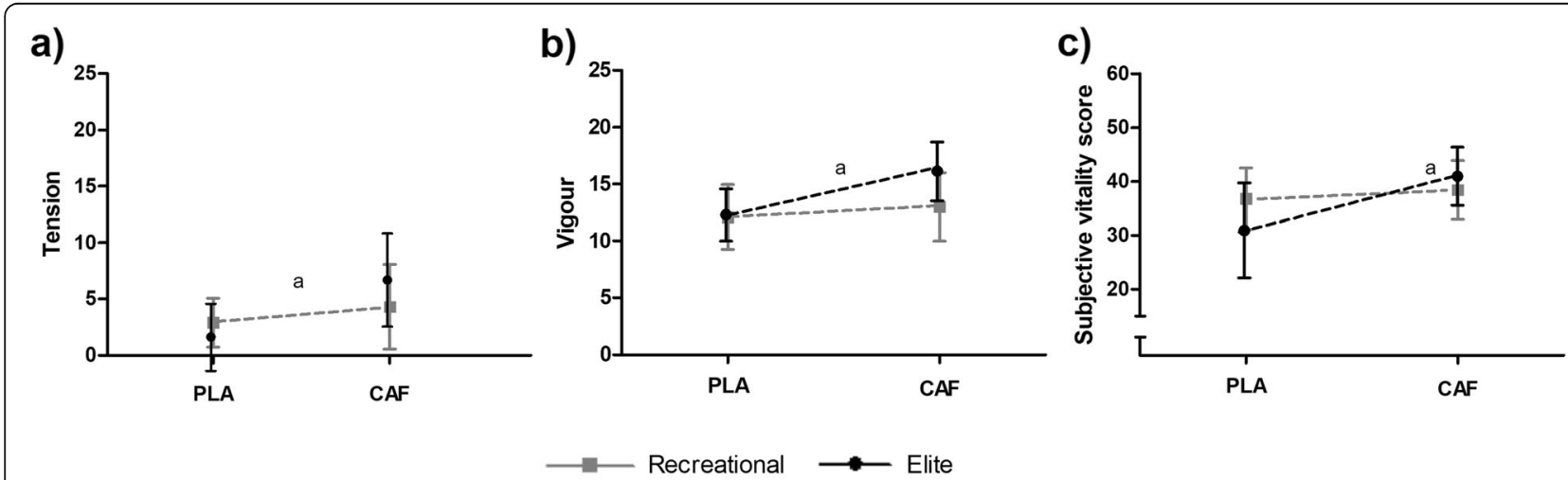

Abbreviations: PLA = placebo; CAF $=$ caffeine; ${ }^{a}=$ Significant differences compared to the PLA values at $p<0.05$

Fig. 1 Panel a shows the scores recorded for the dimension tension. Higher tension scores were reported by elite athletes after supplementation with caffeine compared to placebo; Panel $\mathbf{b}$ shows the scores recorded for the dimension vigor. Scores for vigor were significantly higher after caffeine supplementation in the elite athletes compared to the trained-recreational athletes. Further, elite athletes returned higher vigor scores after supplementation with caffeine compared to placebo; Panel c shows the scores recorded in the SVS. Elite athletes showed larger SVS values after supplementation with caffeine versus placebo. a: significant differences were detected in elite athletes when caffeine was compared with placebo. $b$ : significant differences after caffeine supplementation were detected in elite athletes versus trained-recreational athletes 
ergogenic effect of CAFF on measures of anaerobic performance were independent of the athletes' training level.

In line with prior work, studies have shown that CAFF supplementation produces an increase in peak and average power and that this effect is not conditioned by the performance level of the athlete $[19,54,55]$. Consistently, we observed here that CAFF intake led to a shorter time needed to reach peak power in both experimental groups $(-9.9 \%$ in elite and $22.5 \%$ in trainedrecreational athletes). These data suggest that an athlete's training level does not modify the ergogenic effect exerted by CAFF supplementation on anaerobic performance (i.e., peak and average power). Our results are line with the ergogenic effect of CAFF observed both in elite athletes $[13,35,36]$ and in recreational athletes [37], and also with the improved physical performance noted after the intake of CAFF in trained and untrained athletes [34]. In contrast, Collomp et al. reported an ergogenic CAFF effect in an anaerobic capacity field test (100 $\mathrm{m}$ freestyle swimming) in trained swimmers but not in untrained swimmers [33]. If we consider evidence suggesting that the amount of supplemented CAFF determines its potential ergogenic effect [56-58], it seems reasonable that this variable could explain the disparate results obtained in our study and the report by Collomp et al. [33]. While the dose of CAFF in the present study was personalized $(6 \mathrm{mg} / \mathrm{kg})$, Collomp et al. used a standard dose of $250 \mathrm{mg}(\sim 4.3 \mathrm{mg} / \mathrm{kg})$ [33]. Moreover, as it has been established that CAFF supplementation produces a greater effect on movement velocity as the dose is increased and, especially, as the load is increased [59], the greater amount of CAFF used here could explain our different results to those of Collomp et al. [33].

Another explanation for the different results obtained by Collomp et al. could be the type of physical test used [33]. Thus, while we used a standard test to assess anaerobic capacity (Wingate test), Collomp et al. employed a test that was specific for the athletes tested (i.e., $100 \mathrm{~m}$ freestyle) [33]. This could explain why our trainedrecreational athletes developed more peak power than the elite athletes, although other studies have detected no differences in physical performance between different-level athletes [60,61] or between boxers and physically inactive individuals [62]. Notwithstanding, elite boxers were found to show improved anaerobic performance compared to amateur boxers in an arm cycle ergometry Wingate test $[63,64]$. This could suggest that the higher peak power value recorded in our recreational athletes reflected the greater adaptation of these athletes to maximal efforts executed with the legs, regardless of the specificity of the anaerobic test performed according to the given sports modality. In future work, the ergogenic effect of CAFF should be examined in different level athletes (elite vs. trained-recreational) who practice the same sports activity in physical performance tests specific to the physiological and biomechanical needs of that sport.

The effects of caffeine on anaerobic performance may be explained by both peripheral and central mechanisms. At the peripheral level, the effects of CAFF supplementation, such as enhanced neuromuscular recruitment $[14,15]$ and increased bioavailability of calcium in the myoplasm [16], could explain the positive effect on power production by the muscle and thus explain the ergogenic effects observed in the Wingate test. Centrally, CAFF is an adenosine antagonist, increasing neurotransmitter synthesis $[11,12]$ and nervous system stimulation [65]. How these effects impact RPE and physical performance are still being explored [66]. Studies have shown that CAFF doses of $3-6 \mathrm{mg} / \mathrm{kg}$ give rise to improved performance and reduced RPE in sets of resistance exercise with submaximal loads [67], and physical condition tests in basketball players [68]. In Wingate tests, improved ergometry performance in the arms accompanied by a decline in RPE has been observed [69], as well as improved performance in the legs both in moderately-trained subjects [70] and trained judokas [71, 72]. We could not confirm any beneficial effects of CAFF on RPE here. However, the improved $\mathrm{W}_{\text {avg }}$ levels observed associated with a similar RPE, suggest that CAFF supplementation exerts its positive effects by allowing a greater workload for a given RPE [73, 74], since it would be reasonable to expect lower RPE values at CAFF condition (compared to PLAC) if similar performance were registered for both experimental conditions [75]. Accordingly, CAFF seems to modify the relationship between workload and RPE, reducing RPE for a given load [76]. Therefore, some of the ergogenic effects of CAFF could take place via a diminished sensation of fatigue induced by exercise [77].

As adenosine increases pain and tiredness perception while it diminishes arousal [10], CAFF supplementation, through its effects on adenosine, could have a positive effect on a person's mood state [25, 78]. Some authors propose that an increased mood state via augmented tension, reflects an optimal emotional state to approach a physical task [48]. This determines that small increases in tension levels before exercise could lead to improved performance [79]. Our results indicate that CAFF supplementation has an effect in high-performance athletes. This is consistent with studies in which improved performance was accompanied by increases in tension and vigor and a reduction in fatigue in elite judo athletes [71, $72,80]$. In an attempt to explain such enhanced tension levels only in elite athletes, Lane et al. [81] and Lane and Jarret [82] argued that elite athletes are accustomed to high levels of tension and vigor, and that this leads to 
adaptation to variations met in situations of high physical demands to optimize the state of approaching a task $[26,30]$. This situation is uncommon in recreational athletes. In a study examining fatigue perception, Paton et al. measured sprints in trained cyclists who trained under the effects of caffeine or placebo [83]. The authors noted that acute CAFF intake significantly reduced the feeling of fatigue when executing a repeated highintensity exercise in elite cyclists, coinciding with the findings of studies conducted in moderately-trained [84] and recreational athletes [27]. In our study, the sensation of fatigue diminished significantly in both groups of athletes when taking caffeine as a supplement before conducting a maximum intensity task. This evidence of the effects of CAFF in increasing tension and vigor, and diminishing the sensation of fatigue in the case of elite boxers allows for adaptation to an optimal state for facing maximum intensity explosive actions.

In the depression dimension of the POMS questionnaire, the professional boxers scored higher than the recreational athletes. While several studies indicate that practicing sports improves mood in terms of improving depression [85, 86], two literature reviews [87]. reported that athletes of sports modalities possibly causing concussion (e.g., boxing), showed high prevalence of depression symptoms. Thus, repeated concussion episodes produced after a blow transmitting an inertial force to the brain can give rise to depressive symptoms [88]. This is attributable to a strong correlation observed between athletes with a history of concussion and abnormalities in frontal lobe alpha waves and symptoms of depression [89]. Studies have identified a substantial increase ( $20 \%$ ) in depression symptoms in athletes who have suffered concussion [90, 91]. Further, athletes of sports with a risk of concussion such as American football, rugby or boxing are 2 to 3 times more likely to suffer from depression than the general population [92-94]. This means it could be that the differences detected here between groups were linked to the sports modality of the high-performance athletes (i.e., boxing). Therefore, there is need to evaluate potential associations between concussion and depression symptoms in future studies, in which different athletes' cohorts should be recruited. This would allow researchers to analyze potential underlying mechanisms for depression, in addition to broaden our knowledge regarding concussion-related mental disorders (i.e. anxiety), which have been previously studied in retired athletes $[95,96]$.

\section{Limitations of the study}

Individual caffeine tolerance has been previously associated with decreased ergogenic effect of caffeine supplementation, resulting from an increased activity of the adenosine receptors, along with a decreased $\beta$-adrenergic activity [25]. Unfortunately, it was not possible for us to control for individual's caffeine tolerance on this study, since participant's average caffeine intake was not recorded. Therefore, habituation to caffeine may have been a potential confound variable on our study, and it should be controlled in future research aiming at comparing the ergogenic effect of caffeine between different populations.

Although a set of nutritional guidelines was given to each participant, in order to ensure similar proportions of ingested macronutrients, individual dietary compliance was not assessed. Thus, there is need for control of this variable in future research, in order to fully cancelled potential interactions between supplementation and nutritional factors.

Finally, recruitment criteria associated with strength parameters (i.e. bench press 1RM greater than body weight, and 1RM 1.5 times body weight in full squat) were only applied for the recreational group. Thus, it cannot be fully discarded that between-group differences found for peak and average power resulted from potential strength differences between experimental groups. It is recommended that future research controls for this potential confound variable.

\section{Conclusions}

Supplementation with $6 \mathrm{mg} / \mathrm{kg}$ of CAFF had an ergogenic effect on anaerobic performance, improving average power, peak power and the time needed to reach peak power in elite and in trained-recreational athletes. These improvements took place without a concomitant increase in RPE. Further, CAFF supplementation led to considerable improvements in factors contributing to mood state such as tension, vigor and vitality perception, but only in the elite athletes. In order to be able to generalize our conclusions to different athletes' populations, future research is needed aiming at comparing caffeine's ergogenic effect on recreationally-trained athletes and elite athletes from different sport modalities.

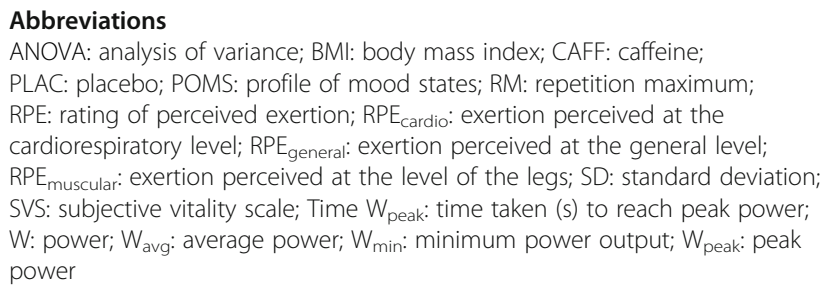

\section{Acknowledgements}

The authors thank the Spanish Boxing Federation (Federación Española de Boxeo) especially Rafael Lozano and Teresa, who gave their permission for their elite athletes to complete the test sessions for this study, and ensured that all diet and resting criteria for participation were fulfilled. We also thank Ana Burton for help with translating the text from Spanish.

Authors' contributions

R.D. and P.J. designed the experiment; R.D., P.J., P.V.H. and A.F.S.J. recruited the subjects, R.D., P.J., P.V.H., A.L.-S., A.P.-L. and A.F.S.J. held the informative 
session; A.J.S.-O. and P.V.-H. checked that subjects followed the diet guidelines and the timing of supplement ingestion; P.V.-H. prepared the supplements and ensured their randomization; R.D., P.J., A.L.-S., A.P.-L. and A.F.S.J. performed the experiments; P.J., A.L.-S., A.P.-L., A.J.S.-O., P.V.-H. and A.S.J.F. analyzed the data; A.L.-R. conducted the statistical analysis; A.L.-S. elaborated the figure; P.J., A.L.-R. and R.D., wrote the manuscript; P.J., A.L.-R., A.J.S.-O., A.L.-S., A.P.-L., P.V.H., and R.D. revised the manuscript; P.J., A.L.-R. A.J.S.-O., A.L.-S., A.P.-L., P.V.H., and R.D. approved the final version of the manuscript. All authors read and approved the final manuscript.

\section{Funding}

This study was financed (supplementation, translation and publication costs) by a grant for the project Effects of caffeine supplementation on psychophysiological responses of performance and fatigue in the Olympic boxing team of the X Call for Research Projects of the UAX and Banco Santander.

\section{Availability of data and materials}

The datasets used and/or analyzed during the current study are available from the corresponding author on reasonable request.

\section{Ethics approval and consent to participate}

This original research study was approved by the Ethics Committee of the Universidad Alfonso X El Sabio, Madrid, Spain.

\section{Consent for publication}

An informed consent was provided to ensure that the subjects had voluntarily expressed his intention to participate in the investigation, after having understood the information given to him, about the objectives of the study, the benefits, the inconvenience, the possible risks and the alternatives, their rights and responsibilities.

\section{Competing interests}

The authors declare that they have no competing interests.

\section{Author details}

${ }^{1}$ Faculty of Health Sciences, Universidad Alfonso X El Sabio, Madrid, Spain. ${ }^{2}$ University of Alcalá, Madrid, Spain. ${ }^{3}$ Faculty of Health Sciences, Universidad Isabel I, Burgos, Spain. ${ }^{4}$ Department of Human Motricity and Sports Performance, Faculty of Education Sciences, Seville University, Seville, Spain. ${ }^{5}$ School of Physiotherapy, Faculty of Health Sciences, Universidad Francisco de Vitoria, Madrid, Spain. ${ }^{6}$ Department of Biomedical Sciences, Faculty of Medicine and Health Sciences, University of Alcalá, Madrid, Spain. ${ }^{7}$ Sports Biomechanics Laboratory, Department of Health and Human Performance, Faculty of Physical Activity and Sport Sciences - INEF, Universidad Politécnica de Madrid, Madrid, Spain.

\section{Received: 28 August 2019 Accepted: 13 December 2019}

\section{Published online: 03 January 2020}

\section{References}

1. Maughan RJ, Burke LM, Dvorak J, Larson-Meyer DE, Peeling P, Phillips SM, et al. IOC consensus statement: dietary supplements and the highperformance athlete. Int J Sport Nutr Exerc Metab. 2018;28:104-25.

2. Kristiansen M, Levy-Milne R, Barr S, Flint A. Dietary supplement use by varsity athletes at a Canadian University. Int J Sport Nutr Exerc Metab. 2005; 15(2):195-210.

3. Petroczi A, Naughton DP. The age-gender-status profile of high performing athletes in the UK taking nutritional supplements: lessons for the future. J Int Soc Sport Nutr. 2008;5:2.

4. López-Samanes Á, Moreno-Pérez V, Kovacs MS, Pallarés JG, Mora-Rodríguez $\mathrm{R}$, Ortega Fonseca JF. Use of nutritional supplements and ergogenic aids in professional tennis players. Nutr Hosp. 2017;34:1463-8.

5. López-Domínguez R, Sánchez-Oliver AJ. Use of sports nutritional supplements in elite rowers: difference between national and international. RETOS - Nuevas Tendencias en Educ. Fis. Deport. y Recreacion [Internet]. 2018 [cited 2019 Aug 27];34:272-5. Available from: https://recyt.fecyt.es/ index.php/retos/article/view/65026/39534.

6. Sánchez-Oliver A, Miranda-León M, Guerra-Hernández E. Estudio estadístico del consumo de suplementos nutricionales y dietéticos en gimnasios. Arch Latinoam Nutr [Internet]. 2008 [cited 2017 Mar 1];58:221-7.
7. Tsitsimpikou C, Chrisostomou N, Papalexis P, Tsarouhas K, Tsatsakis A, Jamurtas $\mathrm{A}$. The use of nutritional supplements among recreational athletes in Athens, Greece. Int J Sport Nutr Exerc Metab [Internet]. 2011 [cited 2019 July 12];21:377-84.

8. Aguilar-Navarro M, Muñoz G, Salinero JJ, Muñoz-Guerra J, Fernández-álvarez M, Plata MDM, et al. Urine caffeine concentration in doping control samples from 2004 to 2015. Nutrients. 2019;11(2):286.

9. Abo-Salem OM, Hayallah AM, Bilkei-Gorzo A, Filipek B, Zimmer A, Muller CE. Antinociceptive effects of novel A2B adenosine receptor antagonists. J Pharmacol Exp Ther U S A. 2004;308:358-66.

10. Davis JK, Green JM. Caffeine and anaerobic performance: ergogenic value and mechanisms of action. Sport Med. 2009;39(10):813-32.

11. Meeusen R. Exercise, nutrition and the brain. Sport Med. 2014;44(1):S47-56.

12. Davis JM, Zhao Z, Stock HS, Mehl KA, Buggy J, Hand GA. Central nervous system effects of caffeine and adenosine on fatigue. Am J Physiol Regul Integr Comp Physiol [Internet]. 2003;284:R399-404

13. Woolf K, Bidwell WK, Carlson AG. The effect of caffeine as an ergogenic aid in anaerobic exercise. Int J Sport Nutr Exerc Metab. 2008;18(4):412-29.

14. Kalmar JM, Cafarelli E. Central excitability does not limit postfatigue voluntary activation of quadriceps femoris. J Appl Physiol. 2006;100(6):1757-64.

15. Plaskett CJ, Cafarelli E. Caffeine increases endurance and attenuates force sensation during submaximal isometric contractions. J Appl Physiol. 2001; 91(4):1535-44.

16. Rousseau E, Ladine J, Liu QY, Meissner G. Activation of the Ca2+ release channel of skeletal muscle sarcoplasmic reticulum by caffeine and related compounds. Arch Biochem Biophys. 1988;267(1):75-86.

17. Allen DG, Westerblad $\mathrm{H}$. The effects of caffeine on intracellular calcium, force and the rate of relaxation of mouse skeletal muscle. J Physiol. 1995; 487(2):31-342.

18. Glaister M, Gissane C. Caffeine and physiological responses to submaximal exercise: a meta-analysis. Int J Sport Physiol Perform. 2018;13(4):402-11.

19. Grgic J. Caffeine ingestion enhances Wingate performance: a meta-analysis. Eur J Sport Sci. 2018;18(2):219-25.

20. Grgic J, Trexler ET, Lazinica B, Pedisic Z. Effects of caffeine intake on muscle strength and power: a systematic review and meta-analysis. J Int Soc Sport Nutr. 2018;15:11.

21. Lopez-Samanes A, Ortega Fonseca JF, Fernandez Elias VE, Borreani S, MateMunõz JL, Kovacs MS. Nutritional ergogenic aids in Tennis: a brief review. Strength Cond J. 2015;37(3):1-11.

22. López-González LM, Sánchez-Oliver AJ, Mata F, Jodra P, Antonio J, Domínguez R. Acute caffeine supplementation in combat sports: a systematic review. J Int Soc Sport Nutr. 2018;15(1):60.

23. Salinero JJ, Lara B, Del Coso J. Effects of acute ingestion of caffeine on team sports performance: a systematic review and meta-analysis. Res Sport Med. 2019;27(2):238-56.

24. Duncan MJ, Oxford SW. The effect of caffeine ingestion on mood state and bench press performance to failure. J Strength Cond Res. 2011;25: 178-85.

25. Sökmen B, Armstrong LE, Kraemer WJ, Casa DJ, Dias JC, Judelson DA, et al, Caffeine use in sports: considerations for the athlete. J Strength Cond Res. 2008;22(3):978-86

26. Ali A, O'Donnell J, Von Hurst P, Foskett A, Holland S, Starck C, et al. Caffeine ingestion enhances perceptual responses during intermittent exercise in female team-game players. J Sports Sci. 2016;34:330-41.

27. Smith A. Effects of caffeine on human behavior. Food Chem Toxicol. 2002; 40(9):1243-55

28. Hanin YL. A study of anxiety in sports. In: William FS, editor. Sport psychology: An analysis of athletic behavior. Ithaca: Mouvement Publications; 1978. p. 236-49.

29. Hanin YL. Emotions and athletic performance: individual zones of optimal functioning model. Essential readings in sport and exercise psychology. Human Kinetics: Champaign; 2007.

30. Nehlig A. Is caffeine a cognitive enhancer? Cunha RA, de Mendonça A, editors. J Alzheimer's Dis [Internet]. 2010 [cited 2019 Jan 17];20:S85-94. Available from: http://www.ncbi.nlm.nih.gov/pubmed/20182035.

31. Kumar N, Warren GL, Snow TK, Millard-Stafford M. Caffeine ingestion with or without low-dose carbohydrate improves exercise tolerance in sedentary adults. Front Nutr. 2019:6:9.

32. Skinner TL, Jenkins DG, Leveritt MD, McGorm A, Bolam KA, Coombes JS, et al. Factors influencing serum caffeine concentrations following caffeine ingestion. J Sci Med Sport. 2014;17(5):516-20. 
33. Collomp K, Ahmaidi S, Chatard JC, Audran M, Préfaut C. Benefits of caffeine ingestion on sprint performance in trained and untrained swimmers. Eur J Appl Physiol Occup Physiol. 1992;64:377-80.

34. Boyett JC, Giersch GEW, Womack CJ, Saunders MJ, Hughey CA, Daley HM, et al. Time of day and training status both impact the efficacy of caffeine for short duration cycling performance. Nutrients. 2016;8(10):639.

35. Goods PSR, Landers G, Fulton S. Caffeine ingestion improves repeated freestyle sprints in elite male swimmers. J Sport Sci Med. 2017;16(1):93-8.

36. Jacobson BH, Weber MD, Claypool L, Hunt LE. Effect of caffeine on maximal strength and power in élite male athletes. $\mathrm{Br} J$ Sports Med. 1992;26(4):276-80.

37. Graham-Paulson T, Perret C, Goosey-Tolfrey V. Improvements in cycling but not handcycling $10 \mathrm{~km}$ time trial performance in habitual caffeine users. Nutrients. 2016:8(7):393.

38. Potach D. Entrenamiento pliométrico y de velocidad. In: Earle R, Baechle T, editors. Man. NSCA Fundam. del Entren. Pers. Barcelona, Spain: Paidotribo; 2002. p. 515-54

39. Bar-Or O. The Wingate anaerobic test an update on methodology, reliability and validity. Sport Med An Int J Appl Med Sci Sport Exerc. 1987:4(6):381-94.

40. McLellan TM, Caldwell JA, Lieberman HR. A review of caffeine's effects on cognitive, physical and occupational performance. Neurosci Biobehav Rev. 2016;71:294-312.

41. Ministerio de Sanidad y Consumo. Real Farmacopea Española. Madrid; 2005.

42. Domínguez R, Garnacho-Castaño MV, Cuenca E, García-Fernández P, MuñozGonzález A, de Jesús F, et al. Effects of beetroot juice supplementation on a 30-s high-intensity inertial cycle ergometer test. Nutrients. 2017;9(12):1360.

43. McNair DM, Lorr M, Droppleman LF. Manual for profile of mood states. San Diego: Educational and Industrial Testing Service; 1992.

44. Fuentes I, Balaguer I, Meliá JL, García-Merita M. Forma abreviada del Perfil de Estado de Ánimo (POMS). V Congr. Nac. Psicol. la Act. Física y el Deport. 1995.

45. Ryan RM, Frederick C. On energy, personality, and Health: subjective vitality as a dynamic reflection of well-being. J Pers. 1997:65(3):529-65.

46. Balaguer I, Castillo I, García-Mertia M, Mars I. Implications of structured extracurricular activities on adolescent's well being and risk behaviors: motivational mechanisms. 9th European Congress of Psychology. 2005.

47. Cuenca E, Jodra P, Pérez-López A, González-Rodríguez LG, da Silva SF, Veiga-Herreros $P$, et al. Effects of beetroot juice supplementation on performance and fatigue in a 30-s all-out sprint exercise: a randomized, double-blind cross-over study. Nutrients. 2018;10(9):1222.

48. Jodra P, Dominguez R, Sanchez-Oliver A, Veiga-Herreros P, Bailey SJ. Effect of beetroot juice supplementation on mood, perceived exercise and performance during a 30 s Wingate test. Int J Sport Physiol Perform. 2019:1-6.

49. Medicine GB. Subjective effort and physical abilities. Scand J Rehabil [Internet]. 1978 [cited 2019 Jan 17];6:197. Available from: https://scholar. google.es/scholar?hl=es\&as_sdt=0\%2C5\&q=Borg\%2C+G.+\%281978\%29.+ Subjective+effort+and+physical+abilities.+Scandinavian+Journal+of+ Rehabilitation+Medicine\%2C+6\%2C+105-113.\&btnG =

50. Lakens D. Calculating and reporting effect sizes to facilitate cumulative science: a practical primer for t-tests and ANOVAs. Front Psychol. 2013;4:863.

51. Cohen J. Statistical power analysis for the behavioral sciences. Technometrics. 1988:31(4):499-500.

52. Ferguson CJ. An effect size primer: a guide for clinicians and researchers Prof Psychol Res Pract. 2009;40(5):532.

53. Richardson JTE. Eta squared and partial eta squared as measures of effect size in educational research. Educ Res Rev. 2011;6(2):135-47.

54. Doherty M, Smith PM, Hughes MG, Davison RCR. Caffeine lowers perceptual response and increases power output during high-intensity cycling. J Sports Sci. 2004;22(7):637-43.

55. Wiles JD, Coleman D, Tegerdine M, Swaine IL. The effects of caffeine ingestion on performance time, speed and power during a laboratorybased 1 km cycling time-trial. J Sports Sci. 2006;24:1165-71.

56. Astorino TA, Terzi MN, Roberson DW, Burnett TR. Effect of two doses of caffeine on muscular function during isokinetic exercise. Med Sci Sports Exerc. 2010:42(12):2205-10.

57. Boiko Ferreira LH, Smolarek AC, Mascarenhas LPG, Oliveira CS, Zandoná BA Schoenfeld BJ, et al. Acute effect of different doses of caffeine on strength and calcium release. Med Sci Sports Exerc. 2018;50(5S):599.

58. Negaresh R, Del Coso J, Mokhtarzade M, Lima-Silva AE, Baker JS, Willems MET, et al. Effects of different dosages of caffeine administration on wrestling performance during a simulated tournament. Eur J Sport Sci. 2019;19(4):499-507.
59. García-Pallarés J, Fernández-Elías VE, Ortega JF, Muñoz G, Muñoz-Guerra J, Mora-Rodríguez R. Neuromuscular responses to incremental caffeine doses: performance and side effects. Med Sci Sports Exerc [Internet]. 2013 [cited 2019 July 12];45:2184-92. Available from: https://insights.ovid.com/ crossref?an=00005768-201311000-00021.

60. Jonvik KL, Nyakayiru J, Van Dijk JW, Maase K, Ballak SB, Senden JMG, et al. Repeated-sprint performance and plasma responses following beetroot juice supplementation do not differ between recreational, competitive and elite sprint athletes. Eur J Sport Sci. 2018;18(4):524-33.

61. Demirkan E, Koz M, Kutlu M, Favre M. Comparison of physical and physiological profiles in elite and amateur young wrestlers. J Strength Cond Res. 2015;29(7):1876-83.

62. Abidin MAH, Ooi FK, Chen CK. Physiological profiles and bone health status of Malay adolescent male boxing, Muay Thai and silat athletes. Sport Sci Health. 2018;14(3):673-83.

63. García Pallarés J, López-Gullón JM, Torres-Bonete MD, Izquierdo M. Physical fitness factors to predict female Olympic wrestling performance and sex differences. J Strength Cond Res. 2012;26(3):794-803.

64. García-Pallarés J, López-Gullón JM, Muriel X, Díaz A, Izquierdo M. Physical fitness factors to predict male Olympic wrestling performance. Eur J Appl Physiol [Internet]. 2011 [cited 2017 Feb 23];111:1747-58. Available from: http://link.springer.com/10.1007/s00421-010-1809-8.

65. Graham TE. Caffeine and exercise metabolism, endurance and performance. Sport Med. 2001;31(11):785-807.

66. Marcora SM, Staiano W. The limit to exercise tolerance in humans: mind over muscle? Eur J Appl Physiol [Internet]. Springer; 2010 [cited 2019 Jan 17];109:763-70. Available from: http://link.springer.com/10.1007/s00421-01 0-1418-6.

67. Duncan MJ, Stanley M, Parkhouse N, Cook K, Smith M. Acute caffeine ingestion enhances strength performance and reduces perceived exertion and muscle pain perception during resistance exercise. Eur J Sport Sci. 2013; 13:392-9.

68. Stojanovic E, Stojiljkovic N, Scanlan AT, Dalbo VJ, Stankovic R, Antic V, et al. Acute caffeine supplementation promotes small to moderate improvements in performance tests indicative of in-game success in professional female basketball players. Appl Physiol Nutr Metab. 2019:44(8): 849-56.

69. Duncan MJ, Dobell AP, Caygill CL, Eyre E, Tallis J. The effect of acute caffeine ingestion on upper body anaerobic exercise and cognitive performance. Eur J Sport Sci. 2019;19(1):103-11.

70. Chtourou H, Trabelsi K, Ammar A, Shephard RJ, Bragazzi NL. Acute effects of an "Energy drink" on short-term maximal performance, reaction times, psychological and physiological parameters: insights from a randomized double-blind, placebo-controlled, counterbalanced crossover trial. Nutrients. 2019;11(5):992.

71. Souissi M, Abedelmalek S, Chtourou H, Atheymen R, Hakim A, Sahnoun Z. Effects of morning caffeine' ingestion on mood states, simple reaction time, and short-term maximal performance on elite judoists. Asian J Sports Med. 2012:3:161-8.

72. Souissi M, Abedelmalek S, Chtourou H, Boussita A, Hakim A, Sahnoun Z. Effects of time-of-day and caffeine ingestion on mood states, simple reaction time, and short-term maximal performance in elite judoists. Biol Rhythm Res. 2013;44:897-907.

73. Desbrow B, Biddulph C, Devlin B, Grant GD, Anoopkumar-Dukie S, Leveritt MD. The effects of different doses of caffeine on endurance cycling time trial performance. J Sports Sci. 2012;30(2):115-20.

74. Laurence $\mathrm{G}$, Wallman K, Guelfi K. Effects of caffeine on time trial performance in sedentary men. J Sports Sci. 2012;30(12):1235-40.

75. Casado A, Moreno-Pérez D, Larrosa M, Renfree A. Different psychophysiological responses to a high-intensity repetition session performed alone or in a group by elite middle-distance runners. Eur J Sport Sci [Internet]. 2019 [cited 2019 Nov 27];19:1045-52. Available from: http:// www.ncbi.n/m.nih.gov/pubmed/30922192.

76. Killen LG, Green JM, O'Neal EK, Mclntosh JR, Hornsby J, Coates TE. Effects of caffeine on session ratings of perceived exertion. Eur J Appl Physiol. 2013; 113(3):721-7.

77. Motl RW, O'Connor PJ, Dishman RK. Effect of caffeine on perceptions of leg muscle pain during moderate intensity cycling exercise. J Pain. 2003:4(6): 316-21.

78. Lieberman HR. The effects of ginseng, ephedrine, and caffeine on cognitive performance, mood and energy. Nutr Rev. 2009;59(4):91-102. 
79. Stevens MJ, Lane AM, Terry PC. Mood profiling during Olympic qualifying judo competition: a case study testing transactional relationships. J Sport Sci Med. 2006;5:143-51.

80. Souissi M, Aloui A, Chtourou H, Aouicha HB, Atheymen R, Sahnoun Z. Caffeine ingestion does not affect afternoon muscle power and fatigue during the Wingate test in elite judo players. Biol Rhythm Res. 2015;46:2918 Taylor and Francis Ltd.

81. Lane AM, Jackson A, Terry PC. Preferred modality influences on exerciseinduced mood changes. J Sports Sci Med [Internet]. 2005 [cited 2019 Aug 27]; 4:195-200. Available from: http://www.ncbi.nlm.nih.gov/pubmed/24431976.

82. Lane AM, Jarrett $\mathrm{H}$. Mood changes following golf among senior recreational players. J Sports Sci Med [Internet]. Department of Sports Medicine, Medical Faculty of Uludag University; 2005 [cited 2019 Aug 27];4:47-51. Available from: http://www.ncbi.nlm.nih.gov/pubmed/24431960.

83. Paton CD, Lowe T, Irvine A. Caffeinated chewing gum increases repeated sprint performance and augments increases in testosterone in competitive cyclists. Eur J Appl Physiol [Internet]. 2010 [cited 2019 Aug 27];110:1243-50. Available from: http://link.springer.com/10.1007/s00421-010-1620-6.

84. Duncan MJ, Oxford SW. The effect of caffeine ingestion on mood state and bench press performance to failure. J Strength Cond Res [Internet]. 2011 [cited 2017 Feb 23];25:178-85. Available from: http://content.wkhealth.com/ linkback/openurl?sid=WKPTLP:landingpage\&an=00124278-201101000-00026.

85. Teychenne M, Ball K, Salmon J. Physical activity, sedentary behavior and depression among disadvantaged women. Health Educ Res [Internet]. 2010 [cited 2019 Aug 27];25:632-44. Available from: http://www.ncbi.nlm.nih.gov/ pubmed/20145009.

86. Brosse AL, Sheets ES, Lett HS, Blumenthal JA. Exercise and the treatment of clinical depression in adults. Sport Med [Internet]. Springer; 2002 [cited 2019 Aug 27];32:741-60. Available from: http://link.springer.com/10.2165/ 00007256-200232120-00001.

87. Solomon GS, Kuhn AW, Zuckerman SL. Depression as a modifying factor in sport-related concussion: a critical review of the literature. Phys Sportsmed [Internet]. 2016 [cited 2019 Aug 27];44:14-9. Available from: http://www. tandfonline.com/doi/full/10.1080/00913847.2016.1121091.

88. Yrondi A, Brauge D, LeMen J, Arbus C, Pariente J. Depression and sportsrelated concussion: a systematic review. Presse Med [Internet]. 2017 [cited 2019 Aug 27];46:890-902. Available from: https://linkinghub.elsevier.com/ retrieve/pii/S075549821730372X.

89. Moore RD, Sauve W, Ellemberg D. Neurophysiological correlates of persistent psycho-affective alterations in athletes with a history of concussion. Brain Imaging Behav [Internet]. 2016 [cited 2019 Aug 27];10: 1108-16. Available from: http://link.springer.com/10.1007/s11682-015-94 73-6.

90. Vargas G, Rabinowitz A, Meyer J, Arnett PA. Predictors and prevalence of postconcussion depression symptoms in collegiate athletes. J Athl Train [Internet]. 2015 [cited 2019 Aug 27];50:250-5. Available from: http:// natajournals.org/doi/10.4085/1062-6050-50.3.02.

91. Yang J, Peek-Asa C, Covassin T, Torner JC. Post-concussion symptoms of depression and anxiety in division I collegiate athletes. Dev Neuropsychol [Internet]. 2015 [cited 2019 Aug 27];40:18-23. Available from: http://www. tandfonline.com/doi/abs/10.1080/87565641.2014.973499.

92. Makdissi M, Davis G, McCrory P. Updated guidelines for the management of sports-related concussion in general practice. Aust. Fam. Physician [Internet]. 2014 [cited 2019 Aug 27];43:94-9. Available from: http://www.ncbi.nlm.nih. gov/pubmed/24600668.

93. Guskiewicz K, Marshall S, Bailes J, McCrea M, Harding HJ, Matthews A, et al. Recurrent concussion and risk of depression in retired professional football players. Med Sci Sport Exerc [Internet]. 2007 [cited 2019 Aug 27];39:903-9. Available from: http://www.ncbi.nlm.nih. gov/pubmed/17545878

94. Decq P, Gault N, Blandeau M, Kerdraon T, Berkal M, ElHelou A, et al. Longterm consequences of recurrent sports concussion. Acta Neurochir. (Wien) [Internet]. 2016 [cited 2019 Aug 27];158:289-300. Available from: http:// www.ncbi.n/m.nih.gov/pubmed/26711286.

95. McMillan TM, McSkimming P, Wainman-Lefley J, Maclean LM, Hay J, McConnachie A, et al. Long-term health outcomes after exposure to repeated concussion in elite level: rugby union players. J Neurol Neurosurg Psychiatry [Internet]. 2017 [cited 2019 Nov 27];88:505-11. Available from: http://www.ncbi.nlm.nih.gov/pubmed/27951526.

96. Kerr ZY, DeFreese JD, Marshall SW. Current physical and mental health of former collegiate athletes. Orthop J Sport Med. 2014:2, 1 Sage.

\section{Publisher's Note}

Springer Nature remains neutral with regard to jurisdictional claims in published maps and institutional affiliations.

\section{Ready to submit your research? Choose BMC and benefit from:}

- fast, convenient online submission

- thorough peer review by experienced researchers in your field

- rapid publication on acceptance

- support for research data, including large and complex data types

- gold Open Access which fosters wider collaboration and increased citations

- maximum visibility for your research: over $100 \mathrm{M}$ website views per year

At $\mathrm{BMC}$, research is always in progress.

Learn more biomedcentral.com/submissions 